J. W. GONGGRYP

\title{
THE EVOLUTION OF A DJUKA-SCRIPT IN SURINAM
}

\author{
Five years is a lot \\ Twenty years is the horizon of most people \\ Fifty years is antiquity \\ WINSTON CHURCHILL
}

By the above standard a script, evolved at the time of the last appearance of Halley's Comet (I9I0), at present should be considered to be an 'antiquity.' Nevertheless, compared with the ages of the scripts generally used, which are reckoned by the thousands of years, the script which is the subject of this paper, is very young indeed. The incidents of its birth might be of interest, not only in themselves, but perhaps also help in understanding the evolution of other systems of writing.

The author of this article, over a period of more than fifty years in connection with his forestry work in Surinam, has known and talked with many people who have interested themselves in the Djuka-script, and from that background this contribution is made.

Morton C. Kahn wrote in I93I (p. 205): "These phonograms were collected for me by Mr. G. deBies, Dutch Government agent at Albina. They were set down by a Bush Negro, named Aflakka, with the aid of an attendant Krutu or assembly. So far as is known, they are in use only among the Aucaners, and their use is limited to the older members, who employ them for purposes of sending messages over long distances. These characters are extremely difficult to collect, and Mr. deBies is to be congratulated on his efforts in this regard. The characters were redrawn for the purpose of publication by Ruth K. Kahn."

There exists some literature in Dutch which throws additional light on the above remarks by Kahn, and perhaps makes clearer the origin of the Djuka script.

In I9I6 Dr. C. Bonne, a physician at the Government Hospital at Paramaribo, saw one of his patients, a Bush Negro by the name of Abéna, of the Aucaner or Djuka tribe, writing strange 


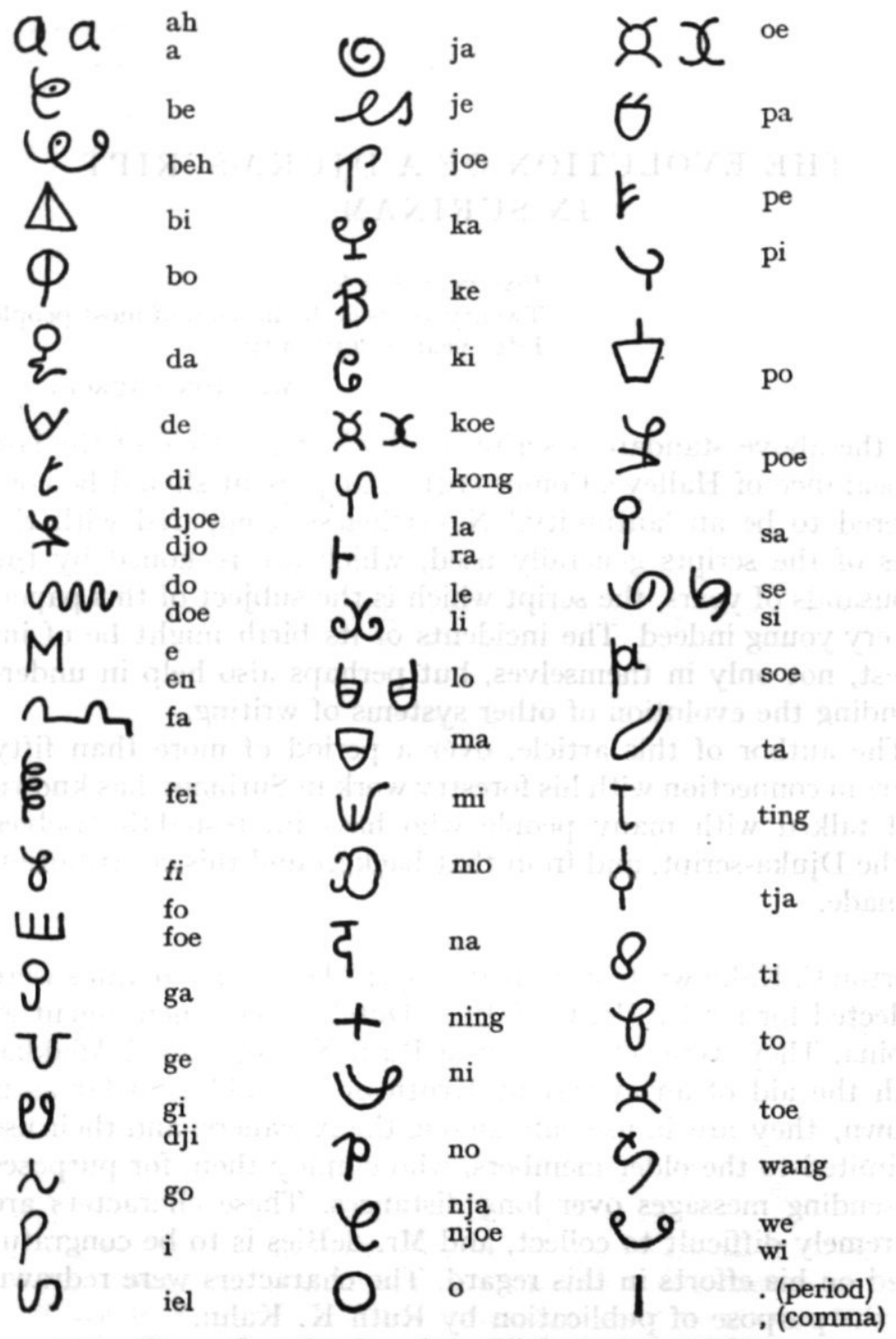

Fig. I. Sound value of the Djuka-script of Afaka.

characters. Abéna was quite willing to explain their significance and said that they were originated by another member of his tribe, called Afaka. Bonne came to know this Afaka, who repeatedly explained to him and to Father Morssink CssR (a catholic missionary), how at the time of Halley's Comet he had 
THE EVOLUTION OF A DJUKA-SCRIPT IN SURINAM 65

a dream in which a Person appeared with a sheet of paper in his hand, ordering him to devise a script for his people. The first should bring the second, the second the third; and so on. Following this vision, he devised a sign, every two or three days, until, in the end he had about 56 characters by which he could write down his thoughts. In I9I7 Bonne made a trip to the Djuka country, and by means of the new script he could send messages, which were understood and acted upon.

In I9I8 both Father Morssink and myself made two trips to the Djuka country, in the interior of the eastern part of Surinam, Dutch Guiana, bordering on French Guiana. Bonne had asked me to get information from the Djukas in relation with the script. I did not know that Afaka had been in contact with Father Morssink, and he, evidently, did not know my interest in Afaka's script. We met and sometimes travelled together. I regret very much, that it was only after about forty years, and after his death, that I got to know Father Morssink's report about these trips.

In November 1918 - it cannot have been with an interval of more than a few days - we visited Granman Amakti, the head of the Aucaner tribe at Drie Tabbetje, without ever discussing the matter with each other. Morssink reports - and I remember the exact words with which Amakti gave vent to his displeasure that Afaka "na wissi wassi man fo bilo nengre" (that wishywashy man from the part of the tribe below Drie Tabbetje on the Tapanahoni) - had made bold to devise a script without first obtaining his, the Granman's permission.

In conversation I tried in vain to bring Amakti and his righthand man, the highpriest Kanapé, to a better appreciation of Afaka. They did not tell me that he already had died or that

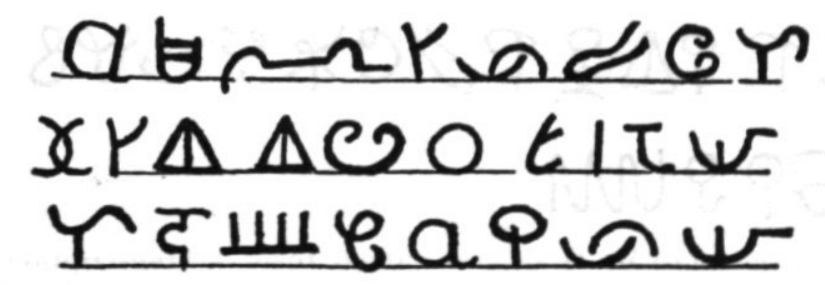

Fig. 2. Note of Captain Alofaisi (1958) - Transcription: ALOFAISI TAKI KONGKUIBI BIGI ODI / TING MI KONG NA FOTO A SA SI MI. Translation: Alofaisi says Gonggryp great greetings. When I come to town he will see me. 
the Christian Missionary was interested. Morssink spoke at an official Krutu or assembly and, unknown to me, pleaded in the same sense as I did. The Djuka chiefs allowed the companion of Father Morssink, an old Saramaccaner, named Antonio, to talk in the Krutu. He recalled that many nations had their own script: Chinese and Javanese have their own way of writing; and now God has given Djuka its own script; therefore, do not reject it. - But to no avail.

Afaka had a second name: Atumisi; and a 'bookname': Usa. On August II, I9I8, Father Morssink had visited the burial place of Afaka, who had died the previous 8th of July. His grave bore a beautifully worked cross with an inscription in Djuka characters: "Masa Atumisi fu da Santa Katoliki Kerki." He had died before he could have been baptized. Father Morssink knelt down together with his yet unbaptized followers, and prayed for him, whom he hoped he could consider as belonging to the Church by the baptism of desire.

Father Morssink supposed - and I agree with him - that the opposition of the Djuka chiefs (staunch supporters of the Djuka Gods) was due to the Christian leanings of Afaka and to a fear of losing privileges connected with old practices and with old superstitions. Morssink had corresponded with Afaka and his frieñds in Djukâ scripipt. He hâd estâblisheed â câtechisism wịth fifty questions and answers in that script. And he found the study

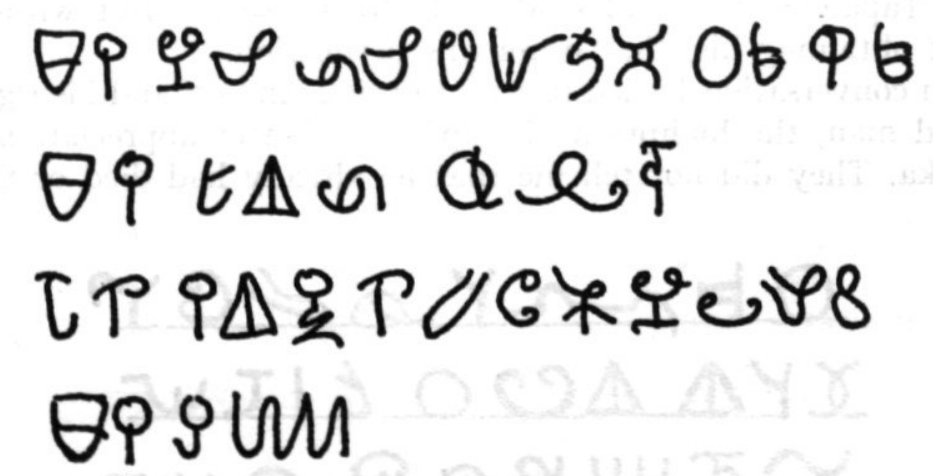

Fig. 3. Note given to Mr. G. de Bies. (about 1930). - Transcription: MASA KANI SENI GI ME WANG TU OLO BOLO / MASA DIBISI ABENA / TING JU SABI DA JU TAKI DJUKA WINTI / MASA GADU. Translation: Mr. Kahn sends giving me one two old shirts. Mr. de Bies, Albina. When you know that you talk Djuka winti. Master God. 
THE EVOLUTION OF A DJUKA-SCRIPT IN SURINAM 67

of this catechism by the children of his correspondents as fruitful as he had experienced in Paramaribo with a catechism in Latin script. Even a child of seven whom he had never seen, knew the lessons perfectly. There were then (november I9I8) more than thirty 'book-men,' people who knew the script, and these were divided over seven of the twelve or fourteen $l o$ 's or sub-tribes, which make out the Aucaner-tribe. Morssink gives the names of the $l o$ 's, which had 'buku-men.' They were: Dikan, Brei, Njamfai, Dju, Misidjan, Pedri, Pulugudu. Father Morssink was jokingly promoted to an eighth, honorary lo. Afaka, in a document he gave to Dr. Bonne about 1916, lists the men and women who then knew the script. They were: Afaka, Abena, Amine, Alofaisi, Dedo, Abopeje, Delipi, Ta-a-kasili, Aja-una, Asiti; ten in all.

In I957 and I958 I tried to trace the distribution of Afaka's script. I got in contact with only one 'bookman,' Captain Alofaisi of Godoholo, of the Dju-lo, an 'opo-nengre,' from the division of Djuka upstream from Drie Tabbetje. I wrote him a letter, in the script, asking how many people knew it. The reply was that he would visit me when he came to town. It is quite impossible that this Alofaisi, a follower of the Djuka-gods, is identical with the Alofaisi registered in Igr6 by Afaka. He is too young. However, he understood my letter, and I understood his.

Granman Amakti had said in IgI 8 that in case Afaka wanted to write, he could learn the 'bakra-script' of the white people. This, of course, cannot be denied. But, on the other hand, the intellectual power demonstrated by an unschooled primitive in

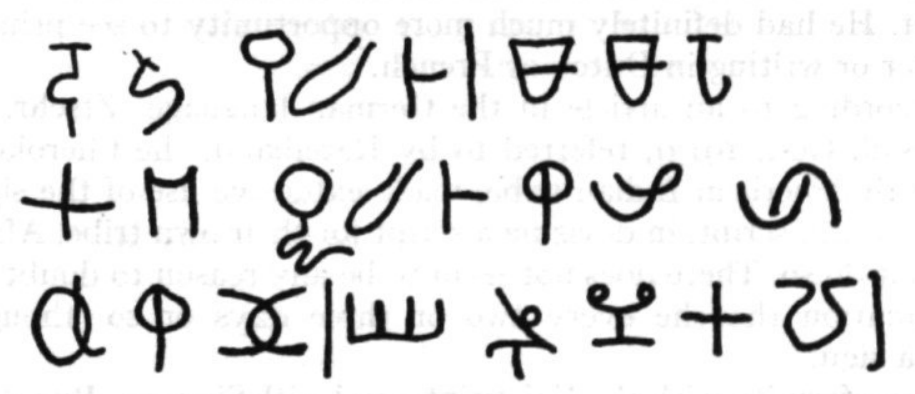

Fig. 4. Note of Abena (1916). - Transcription: NA wang satara mamaTING / NING E DATARA BONI SI / A BOKU FU DJUKA NINGRE. Translation: On a saturday morning (two letters exclamation), Doctor Bonne sees the book from Djuka Negroes. 
producing a usable script for his language, merits the greatest respect. The script remained alive forty years after the death of its founder, without any support by tribal or government authority.

More than twenty years after Bonne's publication, K. Ratelband in I944 pointed out the similarity of the phonograms of Afaka with a script of the Vai tribe in West Africa. His attention in this matter was caught, when he saw Afaka's script in Bonne's publication at the time he obtained the national anthem of the Republic of Liberia in the Vai script. Thirty four of the fiftysix signs of Afaka are identified with signs of the Vai script, also a syllable-script, which has I6 4 characters in all. It was originated in the seventeenth century. The sound value of the signs of the Vai script is not given. The similarity in the form of the characters cannot be denied.

At the time when Ratelband wrote his paper, I told him I felt certain that there was no possibility that Afaka could have had any direct contact with the present-day Vai people. The Djuka tribe was officially named and recognized in 1760 by a peace-treaty with the Dutch at a place called Auca, from which the name Aucaner is derived. They have remained always faithful to this treaty, ready to give armed assistance against enemies of the Dutch, white or black, and fighting especially, allied with the Dutch, against new bands of run-away slaves, often desperados who attacked indiscriminately plantations of the coastal area or Djuka settlements in the interior. However, with the introduction of West-African labourers into French Guiana about I882, there is a little chance that Afaka can have seen some Vai script. He had definitely much more opportunity to see printed matter or writing in Dutch or French.

According to an article in the German language (Ztschr. D. Morgenl. Ges., I9I3), referred to by Ratelband, the Cherokees, a North-American Indian tribe, made extensive use of the signs of the Latin script, in devising a script for their own tribe. Afaka did not do so. There does not seem to be any reason to doubt his explanation that he every two or three days or so 'thought out' a sign.

In conformity with the Vai script - and with Siamese, Burmese, Javanese, and other oriental scripts descended from the Sanskrit-Afaka's script is a syllable-writing, proceeding from the left to the right hand side. There certainly is no reason to think that Afaka had any connection with Sanskrit. 
THE EVOLUTION OF A DJUKA-SCRIPT IN SURINAM 69

Ratelband points out the similarity of Afaka's $A$ and $O$ with our handwriting. It cannot be accidental that the letter $\mathrm{O}$ conforms to the form of our lips in uttering the sound. Consequently it is not impossible that the fathers of our script and Afaka arrived at this sign independently of each other. It cannot be accidental that Afaka's sign for ning, i.e. 'name' in Djukalanguage, is a cross by which every unlettered Djuka signs his name in documents, when required to do so. Nor can it be accidental that the sign for fo ('four' in Djuka language), is figured by four vertical dashes connected by a horizontal line. The signs for $U$ or $k u$ (continental pronunciation), or $u k u$ ('hook' in Djukalanguage), consists of two hooks. This sign has had some further development, no doubt, because it could be mistaken for the sign for $l e$ or $l i$.

Kong ('come' in Djuka-language), is figured by a wandering scrawl and a straight line coming to you, if you have the script in the correct position. Go (the same in Djuka and English), has a similar wandering scrawl with a straight line going from you.

It is possible, that a more intimate knowledge of Djukalanguage and Djuka symbols would give further enlightenment. Afaka cannot be questioned any more as to why he assigned the separate signs to the sounds given. It seems that the instances cited indicate a close connection of the sound value of Afaka's phonogram with his language, and thus make more probable the originality of his script.

Melville Herskovits and Frances Herskovits (1936, plate XV) give a sample of writing produced under a state of winti, and of the normal handwriting of the same individual, an unnamed informant of Paramaribo. They say (p. 83): "One of the things he does under possession, and which he did when possessed in our hotelroom, is to write the language of his winti. We reproduce a sample written while in a state of possession. Since leaving Suriname, we have had several letters from him which contained this writing, included, he explained, as a greeting of his winti to us. Objectively considered, the symbols he employs are consistent, and we have seen him write them with ease. He has not yet solved for himself the meaning of this writing, for he still questions us about the peoples in Africa who know how to write, though he assures us that once the winti is pacified, it will make known to him the meaning of the symbols, and their origin."

No mention is made of Afaka's script. 
There is what could be called a family-likeness between this winti-writing and Afaka's symbols. I have tried, without success, to read the winti-writing. In case the informant of Herskovits was bonafide, it would seem that the characters of the 'wintiwriting' and Afaka's script, both of the same type, could be considered as strengthening the supposition that both sets of characters stemmed from a common deep subconscious. In case the winti-man was pretending, he could have seen samples of Afaka's script and have tried to reproduce them more or less.

There are some differences between the script collected by $\mathrm{Mr}$. De Bies and that published by Dr. Bonne. They can be reduced$$
\text { B日PesPロ }
$$

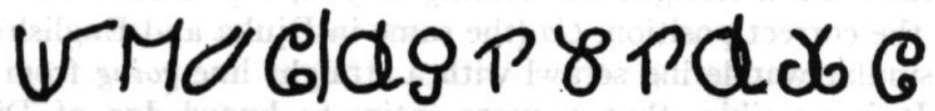$$
\text { w|asYun|char on: }
$$$$
\forall 08 x 6+2516 p e x x \xi
$$

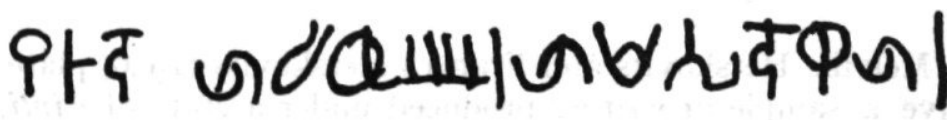

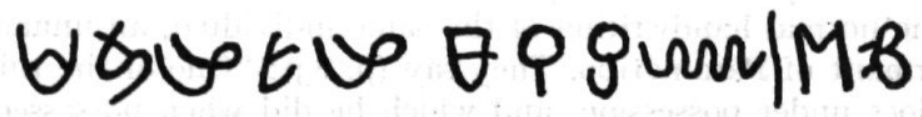$$
\text { Bit }
$$

Fig. 5. Note of Afaka (19r6). - Transcription: KE MASA JEISISI KELESISI / MI E TAKI AGA JU FI JU ALIKI / MI AGA PIMISI AGA LESIPEKI / DE AFILIKA NINGGE DI JU BE PUU NA / SARANA SITAAFU SI DE GO NA BOSI / DE WANNI DINI MASA GADU EKE / PAKARA. Translation: Please, Master Jesus Christ I am talking to You that You hear me, with permission, with respect. The African Negroes whom You have taken from Surinam punishment, since they have gone to the bush, they want to serve Master God like the whites. 
THE EVOLUTION OF A DJUKA-SCRIPT IN SURINAM 7 I

to inconsistencies in the material. E.g. the same sign is given by De Bies for $l e$ or $l i$ and for $s i$. This is a mistake. On the same line De Bies produces the correct sign for $s i$, given also by Bonne and by Captain Alofaisi.

For $b i$ two signs are given by De Bies. That on Kahn's page 207 is the sign for $t i$ or ting, as given on the last line of page 206 and also by Bonne. On the same line'winti' is spelled as to sound 'tingti'. The correct Djuka spelling could be 'wi-ni-ti' (see fig. 3, line 3).

Bonne gives the same sign for $b a$ and $d i$. This sign can only be pronounced $d i$, as indicated by the texts of Abena and of De Bies. Afaka writes bakara as pakara, which he could not have done if he had a sign for $b a$. The alphabet given by me in 'Opbouw' was changed correspondingly.

The signs for cha and $c a$ of De Bies seem to me to be incorrect and redundant, and they have been omitted.

The wavy line under the text by Afaka was explained as indicating the bottom of the page. Maybe the 'bookmen' later on discovered that they could manage also without such a naive implement.

Kahn (de Bies) and Bonne give the characters a different sequence. A rigid sequence makes certain that in summing up the characters no one is forgotten. In figure 1 Afaka's characters are given in order of the Latin alphabet. Added are the published texts (figs. 2-5) together with their transcription and English translation. The catechism of Father Morssink seems to have been lost. But it is perhaps of more interest to reproduce what the Djuka have written on their own account, than what the 'bakra' could graft on their original endeavours.

With which I do not want to substract anything from my appreciation for the work of Father Morssink.

\section{REFERENCES}

Bonne, C.: Het Boschnegerschrift van Afaka. W.I. Gids 2, 1920, p. 391396.

Delafosse, Maurice: Les Vaï, leur langue et leur système d'écriture. l'Anthropologie 1899, no. ro (quoted in Ratelband).

GongGryP, J. W.: De geschiedenis van het Djukaschrift van Afaka. Opbouw, Paramaribo, December 1958, 7 pp.

Herskovits, Melville J. \& Herskovits, Frances S.: Surinam Folklore. Columbia University Press, New York, 1936. 
Kahn, Morton, C.: Djuka. The Bush Negroes of Dutch Guiana. The Viking Press, New York, r93r.

Klingenheben, A.: The Vai script. Africa 6, p. I58-171 (quoted in Ratelband).

Morssink CssR, F.: Reisbrieven. De Volksmissionaris 40, 1919, p. 91-96, I22-1 28, I4I-144, I55-158; 4I, I920, p. 312-320, 346-352.

RATElBAND, K.: Een Boschnegerschrift van Westafrikaanschen oorsprong. W. I. Gids 26, 1944, p. 193-208.

Zeitschrift der Deutschen Morgenland Gesellschaft, no. 73, 1913, p. 58-65 (quoted in Ratelband).

Since the above was written, the journal De West mentioned, 25 February 1960, that Abéna, a captain of the Aucaner tribe, after a prolonged illness died in the hospital of Stoelmanseiland on the Lawa river and, being a Christian, was buried by the Evangelical Brother Axwijk at Karmel, near Sajé on the Tapanahoni river.

Some months before this captain Alofaisie told me that Abéna was his father. Alofaisie is somewhat older than his brother Datra Bonoe, born in 1918, named thus in honour of Doctor Bonne, and baptized Alfonsus by Father Morssink. He is younger than his brother Delei, also mentioned by Father Morssink. Alofaisie, at present the head of the 'bookmen', must have been born around r9r5.

$\mathrm{He}$ is in possession of a pocketbook written, perhaps by him, in the script.

Mr. C. Dubelaar, to whom I showed some copies of pages of this booklet, discovered in part of them a Protestant version of the Lord's prayer. The rest, repeatedly calling 'mi gadoo', 'mi masa', (my God, my Lord), evidently also had religious intent. But untill now we could not understand its meaning. 